\title{
Two distinct perspectives on pneumatology - similarities and differences between The Romanian Pentecostal and Evangelical theology
}

\author{
EUGEN JUGARU*
}

This article aims to compare and analyse two different perspectives of pneumatology: within the Pentecostal and the Evangelical perspective. In spite of many doctrinal tangents with the Evangelical theology, the Pentecostal has its own spirituality and theological accent, especially in the field of pneumatology. The two differences centre on baptism in the Spirit and the gift of prophecy. From a Pentecostal practical perspective, the spiritual gifts continue to play an important role for the contemporary church. Although there are differences in their theological approaches, the Pentecostals and the Evangelicals found the common ground in forming the Evangelical Alliance of Romania and working together for about a quarter of Century.

Keywords: Evangelical, Pentecostal, pneumatology, gifts of the Spirit, prophecy

\section{The Pentecostals contribution on contemporary theology}

The Pentecostal contribution to theological research rests not on a scientific biblical exegesis but on a vivid understanding of the work and gifts of Holy Spirit. It was not a strong and articulated theology that characterized this movement, but a different spirituality that included a warm love and a deep spirit of sacrifice for others, a great desire for prayer, and a passion for mission. The attention towards the development of theology, based on a high exegetical task or on theological writings was very weak among Pentecostals at the beginning of the movement, but, recently there has been an explosion of Pentecostal theological scholarship which works to elaborate and articulate Pentecostal theological works. ${ }^{1}$

This contribution raises a fresh discussion between theologians about the spiritual gifts of the Holy Spirit such as baptism in the Spirit, the gift of prophecy, the gift of healing and other such spiritual gifts which play an important role in Pentecostal spirituality. In spite of this perspective, the core

\footnotetext{
*Eugen Jugaru, $\mathrm{PhD}$, lecturer to the Pentecostal Teological Institute of Bucharest. Adress: Pentecostal Teological Institute of Bucharest, B-dul Uverturii, nr. 210-220, Romania; e-mail: ejugaru50@gmail.com.

1 Mark J. Cartledge, "Pentecostal Theology" in: Amos Yong, C. Mel Robeck (eds.), The Cambridge Companion to Pentecostalism, Cambridge 2014, p 266.
} 
of Pentecostal faith rests not on pneumatology but on Christology, where the doctrine of salvation is understood not by the person of the Holy Spirit, but by the grace of God, and by faith in Jesus Christ's atonement. The Pentecostal theology includes not only the articles about the Holy Spirit but also includes articles about the whole Christian theology. Regarding the increased attention to pneumatology, Mark Cartledge says that "the Pentecostals have placed the Spirit, if not centre stage, then at least on the stage." ${ }^{2}$ This reality opens communication channels between Pentecostals and other Evangelicals ${ }^{3}$ since both groups have the same theological understanding about the major Christian doctrines.

Another example of this improved communication is the birth of Evangelical Alliance of Romania 25 years ago. ${ }^{4}$ The Pentecostal worship is focusing on Jesus Christ, not on the Holy Spirit, even if the worship is led by a spontaneous guidance of the Spirit which brings a certain freshness and dynamism. ${ }^{5}$ The Pentecostals, as all orthodox Christians have the same theological understanding as all major Christian doctrines and ecumenical Councils, but they believe that the restoration of the spiritual gifts of the Holy Spirit is possible in modern times. The conclusion is that the difference between Pentecostals and other Evangelical Christians rests neither upon the understanding of the personality of the Holy Spirit - all of them are Trinitarian - nor upon the work of the Holy Spirit, but upon spiritual gifts. The Pentecostal theologian Kärkkäinen noticed that in traditional theology the role of the Spirit was

\footnotetext{
2 M. J. Cartledge, "Pentecostal Theology", p. 265.

3 The Evangelical Christians which I refer here are the Baptists and the Evangelical brethren. Even in Romania there are other Evangelicals Churches as Reformed Church, the Evangelical C.A. Church, the Evangelical Lutheran Church, the Unitarian Church, in this paper I am referring to those who formed the Evangelical Alliance (A. E. R.) soon after the revolution from 1989.
}

4 The first meeting of the Pentecostals, Baptists and Evangelical brethren leaders having the purpose to form the Evangelical Alliance of Romania took place in Bucharest on the 25th April 1990, at the Baptist Church on the Iuliu Valahori street. The Pentecostals representative was the Emil Bulgar, the Baptist representative Vasile Talos and the Evangelical brethren representative was Silviu Cioata. All of them were the leaders of their communities. The idea of forming this Alliance after the pattern from England and United States belongs to Iosif Ton, a Baptist minister which studied theology in Oxford. The purpose of the Evangelical Alliance in Romania was not for theological debates upon certain doctrinal issues, but for developing common projects as evangelistic meetings, defending the religious minorities' rights, holding Christian conferences, radio and TV Christian programs and so on. First large meeting of about 4500 Christian belonging to the Evangelical Alliance took place on the 4-5th of November 1990 at Palace Hall in Bucharest. (https://aliantaevanghelica.wordpress. com, 18th of July, 2015).

5 Veli-Mätti Kärkkäinen, Pneumatology, Grand Rapids, MI. 2002, p .91. 
Two distinct perspectives on pneumatology - similarities and differences

quite reserved and limited, but today theologians show a fresh interest regarding "the experience and spirituality of the Spirit."

\section{The Evangelical Alliance of Romania perspective about the person and work of the Holy Spirit}

Soon after the Revolution of 1989 in Romania the Evangelical Alliance was formed which includes the Baptist church, the Brethren church $^{7}$, the Pentecostal Church, an Evangelical group of the Lord's Army and a group of Christians from the Lutheran Church in Bucharest. The Statute of A.E.R. stipulates in art. 5: "we all have a common core of belief around which we are united, while we respect our religious differences." 8

The Evangelical Alliance theological statements about the work of the Spirit are very general and flexible enough that they do not hinder or offend other Christian denominations. It is a general Christian approach, not a specific understanding of Pentecostal doctrinal, and is a common ground where every Christian can feel theologically comfortable. Thus according to the Evangelical Alliance of Romania Statement of Faith, the belief in one God is affirmed, eternally existing in three persons: Father, Son and Holy Spirit. Referring to man's salvation from sin, the Statement said that: "We believe that for the salvation of lost and sinful man, regeneration by the Word of God and the Holy Spirit is absolutely necessary." Spiritual presence of the Holy Spirit in the believers' life is a reality which enables them to live a good life and be ready always to give testimony of personal faith. Also, the Holy Spirit played a very important role in the spiritual unity that develops among believers who are born again. The theological teaching of the Evangelical Alliance

6 Idem, Holy Spirit and Salvation, Louisville 2010, p. xxiv.

7 There are very interesting and useful information about the history of the Romanian Brethren church in Ieremia Rusu, Ph. D.work, Cine sunt Creștinii după Evanghelie? According with Ieremia Rusu research, the Brethren church from Romania belongs to a larger European Evangelical family, with deep roots in the Brethren movement from Great Britain since the beginning of XIX-th Century. Unlike Pentecostals and Baptists, Evangelicals have a different ecclesiology, named by Ieremia Rusu as theocratic congregationalism. This form of ecclesial organization underline the spiritual leadership of Christ as head of the church, principle of democracy through decision-making power of the individual members of the church and local church autonomy. Ieremia Rusu, Ph. D.work, Cine sunt Creștinii după Evanghelie?, București 2011.

8 Statut A.E.R., PDF document. I owe this PDF reference by courtesy of mr. Virgil Achihai, the President of Alianța Evanghelică din România. The latest version of the Statut was adopted during A.E.R. Congress, 3-4th of Juny, 2011 in Oradea, viewed on 18th of July 2015.

9 Crezul evanghelic AER, PDF document. By permission of Virgil Achihai, the President of Alianța Evanghelică din România, viewed on 18th of July 2015. 
about the Trinity is universally recognized so that "God is thereby - beyond being wholly other than us (as Father) and wholly one of us (as Son) - wholly in us and through us (as Spirit)."10

Promoting this general teaching about the Holy Spirit, the Evangelical Alliance, which has been active for a quarter of century until today in Romania, makes it possible that each of the Christian denominations represented here can have the feeling of belonging and working in unity with other Christians for common goals and projects.

\section{The doctrinal similarities on pneumatology between the Pentecostals and Evangelicals in Romania}

The emergence of the Pentecostal movement at the beginning of the 20th Century had a beneficial effect on other Evangelical movements because it challenged them to approach a deeper understanding about the work of the Spirit and to assess their beliefs on this subject. The Romanian Pentecostal leader, Trandafir Sandru opposed some Pentecostals who tried to move the Christological accent into the pneumatological framework. He highlighted four major works performed by Holy Spirit in the Christian life as: repentance, the new birth, baptism in the Spirit, and the sanctification of life. ${ }^{11}$ Except for one of them (the baptism in the Spirit), the rest of these teachings are common for all Evangelical theology.

It is easy to notice that the Pentecostal doctrinal cores of bibliology, soteriology, anthropology, theology (as teaching about the triune God), and other theological issues are similar to the Evangelical theology. The list of some special works of the Holy Spirit also contained repentance for sins, renewal of life (some call that experience the birth from the Spirit), justification by faith, and the work of the Holy Spirit in the sanctification of Christian life through the atonement of Jesus Christ. All of these are similar in both the Evangelical and Pentecostal theologies.

The Pentecostals as well as Evangelicals share a similar perspective regarding the supernatural inspiration and the inerrancy of the Bible. The Pentecostals and their Evangelical brothers both adopted the Chicago declaration on inerrancy of the Bible ${ }^{12}$. In this declaration it is written that: "We affirm

\footnotetext{
10 Rodman Williams, The Era of the Spirit, Plainfield 1971, p. 12.

11 Trandafir Sandru, Lucrarea Dubului Sfânt, Oradea 2009, p. 131-148.

12 The Chicago Statement on Biblical Inerrancy, was produced at an International Summit of Evangelical leaders (1978), sponsored by International Council on Biblical Inerrancy and signet by nearly 300 Evangelical scolars. For more information see: www.bible-researcher. com/chicago1.html, viewed on 18th of July 2015.
} 
that the Holy Spirit bears witness to the scriptures, assuring believers of the truthfulness of God's written Word. We deny that this witness of the Holy Spirit operates in isolation from or against Scripture" (Art. XVII) ${ }^{13}$. For the Pentecostals like Mark Cartledge, the Holy Spirit gives spiritual understanding in studying, living and applying the biblical teaching to daily life: "the engagement with the Scripture is not just an intellectual exercise for the sake of extrapolating true propositions, but a dynamic interaction with a living Word through which the Holy Spirit continues to speak today." ${ }^{14}$ It should be noted that Pentecostal charismatic experiences of prophecy do not overshadow the Scriptures. The prophetic messages for instance are analysed in the light of Bible teaching, and no one claims the right to add or to remove certain scriptures out of the Bible. For all non-cessationists, the prophecy is not seen as an additional source of truth besides the Bible, but as a word from God for somebody regarding a certain peculiar situation of life. Having the same understanding and respect about the Bible, the Pentecostals and Evangelicals are able to work together in preaching or in joining efforts for international mission. It is obvious that if somebody proves lack of respect for the Word of God there cannot be a real fellowship, but Pentecostals, and Evangelicals keep the same high value on the Bible.

Another theological similarity between Pentecostals and all Evangelicals rests on Paul's teaching about the fruit of the Spirit (Gal.5:22-23). A common perspective about the work of the Spirit is that special agape which overwhelms the Christians and brings them into a spiritual family, baptized them in the body of Christ as Paul says: "For in one Spirit we were all baptized into one body - Jews or Greeks, slaves or free - and all were made to drink of one Spirit" (I Cor. 12:13). By this tie of brotherly love, Pentecostals and Evangelicals are strong, and the unity of the Spirit is so deep and intense that "customary rationales for separateness (theological, ecclesiastical, liturgical, social) collapse under the impact of the Spirit." 15

The presence of the Spirit in Christian hearts is necessary because this spiritual presence brings heavenly peace, an over whelming joy, freedom in worship, spiritual liberty, a fresh inspiration or spiritual anointing for preaching with conviction, and the list can go on and on. Being filled with the Spirit, someone does not gain only an experience of deep emotions, but "fflling with the spirit is the way in which the values of the gospel are concretized, the

13 Chicago Statement on Biblical Inerrancy, http://www.bible-researcher.com/chicago1. html,viewed on 6th Nov., 2014.

14 M. J. Cartledge, "Pentecostal Theology", p. 255.

15 R. Williams, The Era, p.15. 
means by which the presence of Jesus is embodied in the world [...] filling with the spirit is no end in itself but a venue for God's presence in the vagaries and pressure of human community." 16 Not only Evangelicals but also the Eastern-Orthodox theological affirmations underline the important role of the Holy Spirit in Christian life. Without the Holy Spirit's impulses, men cannot comprehend God's special works and God's soteriological message. The Holy Spirit brings together the spiritual and created world, sensitizes spiritual insight of Christians, and pulls down the fences of divisions between Christians. As the Orthodox professor Constantin Coman says: "God's Spirit is the ontological bridge between the uncreated world of deity and the created world." 17

\section{Different understanding regarding pneumatology between Pentecostals and Evangelicals}

Unlike Evangelical theology, the Pentecostal theology has a stronger pneumatological accent. The difference between the Pentecostals and the Evangelicals rests neither upon the understanding of the person of the Holy Spirit, nor about the Trinity, nor even upon the fruit of the Spirit, but upon the works and gifts of the Holy Spirit, especially the gift of prophecy and the baptism in the Spirit. The Pentecostal preachers and pastors find support for these different gifts from their personal understanding of certain scriptures, especially from the New Testament but also from their personal changing life experiences.

A critical matter in the Pentecostal understanding of the dynamic work of the Holy Spirit is that this approach does not exactly match in traditional classical theological categories. Rodman Williams says that Christian inherited theology addresses the work of the Holy Spirit in creation, in incarnation, in regeneration, in sanctification, in word and sacraments, in redemption; but these categories do not cover fully the dynamic work (except maybe the new birth) of spiritual gifts in Christian life. ${ }^{18}$ The difficulty in addressing this issue becomes real because the movement of the Spirit, beyond the renewal of the life and justification, cannot be properly grasped in words. It is something dynamic and active; it is an outpouring and filling, it is a "wind and fire" that push the Christian to praise and to witness the Name of the Lord. The filling of the Spirit did not happen to the church as an institution, but to the people, and in the people; ${ }^{19}$ while the gift of the speaking in tongues is for the people's

16 John R. Levison, Filled with the Spirit, Grand Rapids 2009, p. 269.

17 Constantin Coman, Erminia Duhului, București 2002, p. 280.

18 R. Williams, The Era, p. 39.

19 Ibidem, p. 56. 
personal edification. In any event, prior to receiving the gift of the Spirit, it is necessary for faith to dwell in the heart of people: "The Holy Spirit is granted, therefore, to those who have already been sanctified by faith." 20

As it was noted, the theological distinction between Pentecostals and Evangelicals is in the field of spiritual gifts. While the Evangelicals, or most of them maintain that the prophecy, the speaking in tongues and other manifestation of the Spirit ceased sometime during the first Century, - the Baptists pay almost no attention to spiritual gifts since in their Confession of Faith, these are not even mentioned ${ }^{21}$ - the Pentecostals affirm that these spiritual endowments are available today for those who seek them..$^{22}$ In Pentecostals' understanding, by the gift of prophecy, God communicates His messages to a certain person or church in a very personal way, so that "through frail human instruments the Spirit speaks the Word of the Lord." 23 Prophecy is God addressing men, because prophecy is not the result of men's reflection but a message from the Holy Spirit for edification of the community. According with Yves Congar, the prophecy is important to exhort, and to encourage, but at the same time "The great rule is that the purpose of these gifts is to edify and to be useful to others and to the community as such." ${ }^{24}$ For Evangelicals, prophecy is the same thing as preaching: "The gift of prophecy is manifested today in the church by prophetical preaching when a revealed word from the Bible is applied to people under the guidance of the Holy Spirit." 25 The Pentecostals do not reject the concept of prophetical preaching but they see prophecy in a new light. Prophecy is different than preaching or teaching because by prophecy the articulated message does not spring from human reflection but by the inspiration of the Spirit. As Rodman Williams says: "Preaching is the proclamation (kerygma) of the Good News. Teaching is instruction (didache)

20 Gonzalo Haya-Prats, Empowered Believers, Eugene, Oregon 2011, p. 237.

21 http://www.baptistnet.ro/resurse/articole/marturisirea.doc , viewed on 21st May 2015.

22 John Tipei, Duhul Sfant, Metanoia, Oradea 2003, p. 326-338. J. Tipei shows that cessationist perspective is based on a few ideas as: Paul's Statement that the prophecy will cease and also the miraculous gifts (I Cor. 13:8-13), these gifts ceased when the last Apostle died, believing in the gift of prophecy will undermine the authority of Bible, miraculous manifestations have ceased throughout history, today we no longer need for miraculous gifts because by the Bible we come to know God's will, Jesus warned that in the end times will come many false prophets and many deceivers, or that today there is no need of miracles for medicine developed. J. Tipei is bringing a Pentecostal perspective upon this issue showing the continuing of spiritual gifts and also the necessity of these for the church today.

23 R.Williams, The Era, p. 27.

24 Yves Congar, The Word and the Spirit, San Francisco 1986, p. 63.

25 Ieremia Rusu, Cine sunt creștinii după Evanghelie?, București 2011, p. 123. 
in sound doctrine, but is not prophecy (propheteia)." ${ }^{26}$ The one who brings the prophecy does not prepare the prophetical message in advance, nor have a knowledge in advance what he/she will bring forth by prophecy. He or she just delivers the prophetical message under the inspiration of the Holy Spirit, and it speaks a word of the Lord beyond human limited understanding, a word which often challenges us. ${ }^{27}$ Moreover, as Gonzalo Haya-Prats noted, there is a spiritual joy when a prophetical message is issued: "We discover in the prophetic gift an aspect of exuberant joy in the knowledge and praise of God that corresponds also to the gift of the Spirit, even though only as an historic anticipation of his eschatological aspect." ${ }^{28}$ From a different perspective, the Evangelical understanding is that the gift of prophecy ceased when the canon of the Bible was finished.

The Declaration on Faith of the Pentecostal Church of God refers to the baptism in the Spirit as an experience which follows after, not before regeneration: "We believe in the baptism with the Holy Ghost subsequent to a clean heart" (Art. 8) ${ }^{29}$ This spiritual baptism is not the same with the experience of conversion, baptism in the Spirit may occur simultaneously or after conversion, but is not identical with conversion. ${ }^{30}$ Baptism in the Holy Spirit it is seen by the Pentecostals as an experience of being overwhelmed or inundated by the Spirit, when the whole human being is affected by the Spirit, is "an experience of the divine self-disclosure. This is the gracious gift of God; our response is absolute self-surrender, symbolized in part by our speaking in other tongues as enabled by the Spirit." 31

A similar perspective occurs in Catholic renewal, understanding, and practice where the subject is "invaded by the power of God, who seizes hold of his whole being - his heart, his mind and his feelings. He is perhaps conscious of a gentle inner pressure which makes tears flow. A desire to give thanks rises from his heart to his lips, and this may be expressed as praying in tongues." 32 This spiritual baptism is distinct from and subsequent to conversion. ${ }^{33}$ According with Rodman Williams, baptism is not "subjugation, or absorption,

26 R.Williams, The Era, p. 28.

27 CynthiaM. Campbell, "We Believe in the Holy Spirit, Who Has Spoken through the Prophets" in: Fire \& Wind, Joseph Small (ed.), Louisville 2002, p. 44.

28 G. Haya-Prats, Empowered Believers, p. 238-39.

29 http://www.churchofgod.org/beliefs/declaration-of-faith, viewed on 10.11.2014.

30 R. Williams, The Pentecostal Reality, Plainfield 1972, p. 62.

31 Amos Yong, Discerning the Spirit(s), Sheffield 2000, p. 167.

32 Y. Congar, I Believe in the Holy Spirit, vol. II, New York 1997, p. 196.

33 M. J. Cartledge, "Pentecostal Theology”, p. 258. 
or translation, but the actualization of a dynamic whereby the whole person is energized to fulfil new possibilities." ${ }^{4}$ For the Pentecostals, the teaching about baptism in the Spirit and the fervent prayers for this spiritual empowerment is a very important spiritual activity. Actually, Pentecostals refer to this spiritual event as a baptism because, similar to when somebody is baptized in water, the whole person is submerged in water or, in the case of spiritual baptism, the person is submerged in the Holy Spirit. Also, speaking in tongues was seen as an exterior evidence of baptism in the Holy Spirit was the most distinctive and in the same time the preoccupation of early Pentecostal experience. ${ }^{35}$ Linking the two together (speaking in tongues and baptism in the Holy Spirit) the Pentecostals brought a remarkable contribution to the field of pneumatology. According to a Pentecostal understanding, speaking in unknown tongues is a spiritual gift which brings spiritual edification for the person who prays (I Cor.14:4). It is extra-rational because it is not the ordinary language of the speaker and also because it is not the result of the speaker's own rational reflection. ${ }^{36}$ This perspective is based on Paul's teaching in I Corinthians 14:2, 4 where Paul says that "One who speaks in tongues edifies himself; but one who prophesies edifies the church." In this case those who are speaking in tongues address God not men. They worship in spirit through the Spirit. In this way is expressed "in the most intense, deepest, and highest possible way the unutterable yearnings of the soul of the Christian to give praise and blessing to the God who made him, who redeemed him in His Son, and who has poured forth His own Spirit." 37 The Pentecostal theologian Amos Yond warns Pentecostals regarding their understanding of glossolalia that this spiritual gift can become routinized as an end in itself when the focus is on the glossolalist rather what the Spirit wants to accomplish, "it can estrange and alienate rather than bring about solidarity in a congregation." ${ }^{38}$ It is interesting that where some non-Pentecostals see irrational nonsense, the Pentecostals see a spiritual phenomenon and a deeply spiritual communication of praise or intercession. While the Christians are waiting actively for the second coming of Jesus, the Holy Spirit distributes spiritual gifts manifested as "glossolalia or prophecy as exultant doxology and an extraordinary degree of joyous exultation." ${ }^{39}$ The

\footnotetext{
34 R. Williams, The Pentecostal Reality, p. 12.

35 Grant Wacker, Heaven Bellow: Early Pentecostal and American Culture, Harvard 2001, p. 42.

36 R. Williams, The Pentecostal Reality, p. 49.

37 Idem, The Era, p. 31.

38 A. Yong, Discerning the Spirit(s), p. 180.

39 G. Haya-Prats, Empowered Believers, p. 235.
} 
spiritual gifts are important to equip Christians for spiritual or social service, not for gaining the salvation, or as James Dunn says, "One does not enter the new age or the Christian life more than once, but one may be empowered by or filled with the Spirit many times." 40

The Evangelicals perspective regarding the baptism in the Spirit is different than Pentecostals. For instance, they consider that the baptism in the Holy Spirit happens in the moment of conversion, simultaneously with the new birth. ${ }^{41}$ The Evangelicals understand baptism of the Spirit as an important spiritual experience is "the act by which God makes us members in the body of Christ. The body of Christ is the church, and we as church members are also members in the body of Christ." ${ }^{\prime 2}$ Ieremia Rusu, one of the leaders of the Brethren Church presented a definition of baptism in the Spirit in this way: "The baptism in the Spirit is the work of our Lord Jesus Christ which bestows for the believer the Holy Spirit, incorporating him into His spiritual body which is the church and identifying him in His (Christ) death and resurrection... he is integrated in the Lord Jesus Christ as branches on the vine, and as a member in the spiritual body of Christ, the church." ${ }^{43}$ According with the Brethren's belief as synthesized in their Confession of faith, "The Holy Spirit baptizes those who believe (in Christ), into the Body of Christ, the Church, when they return to God and seals them.." ${ }^{44}$ The baptism in the Spirit, as is understood by Pentecostals is a strange teaching for most of Brethren and Baptists. The Pentecostal understanding about the baptism in the Spirit was often criticized by non-Pentecostals. For instance, James Dunn a well-known Evangelical scholar rejected this Pentecostal subsequent experience following conversion because he saw the baptism in the Spirit and conversion as the same experience: "to become a Christian, in short, is to receive the Spirit of Christ, the Holy Spirit. What the Pentecostal attempts to separate into two works of God is one single divine act." ${ }^{35}$ Another perspective, different than the classical Pentecostal, is the Canadian Evangelical theologian Clark Pinnock. He linked water baptism with Spirit baptism; because his understanding was that the water baptism symbolized Spirit baptism. ${ }^{46}$

40 James D. G. Dunn, Baptism in the Holy Spirit: A Re-examination of the New Testament Teaching on the Gift of the Spirit in Relation to Pentecostalism Today, London 1975, p. 54.

41 I. Rusu, Cine sunt, p.72.

42 Ioan Bunaciu, Exegeza textelor biblice controversate, București 1999, p. 160.

43 I. Rusu, Cine sunt, p. 77-78.

44 Mărturisirea de Credință a BCER-UBCE, cap.II, C, "God the Holy Spirit".

45 J. Dunn, Baptism, p. 96.

46 Allan Heaton Anderson, An Introduction to Pentecostalism, Cambridge 2014, p. 185. 
This topic opened a new way for theological debates, and the perspective encompasses a large spectrum of understanding. Gordon Fee suggested that the Pentecostals cannot claim that speaking in tongues was normative but was a repeatable event. ${ }^{47}$ The Pentecostal scholar, Robert Menzies brought his own perspective regarding this issue. He linked the gift of Spirit with the external sign of speaking in tongues: "when one receives the Pentecostal gift, one should expect to manifest tongues, and this manifestation of tongues is a unique demonstrative sign that one has received the gift." 48

From the Pentecostal perspective, God is willing to pour His Spirit over all flesh but this desire does not force someone to receive it unless that person recognizes this spiritual need and has a strong desire for that; to ask, seek, thirst, and to have openness for that spiritual blessing. Seeking the spiritual gifts, or asking for baptism in the Spirit does not mean that the Pentecostals replace the centrality of Christ with the work of the Spirit, but uphold the gracious gift of God toward them and total dependency on God in the Christian pilgrimage. As Rodman William says: "There is no leaving Christ behind for a different centring in the Holy Spirit, for it is precisely through Christ that the event of the Spirit occurs." ${ }^{49}$ The presence of the Spirit in a Christian's life is important since "the primary purpose of this infilling of the Spirit is to endow us with the power to do the works of Christ." 50

The Pentecostals encourage their brotherhood to seek after the spiritual gifts, but not to consider that this spiritual gift makes somebody special or superior to others; but because these spiritual gifts are God's blessings to the community of His people. Besides that, the Christian's responsibility is to open the heart for the gift of God as an eschatological gift and expect that blessed and unpredictable event to occur at any time.

\section{Love as a fruit of the Holy Spirit - the bridge of acceptance among Christians}

Above all kinds of charisma or personal skills, love is the foundation and pinnacle of the Christian spiritual profile. The real Christian love, as a gift of the Spirit, knows no barriers, it overflows abundantly in family, in churches and in society. In this post-modern time, Christian love opens the door of

47 Gordon Fee, Gospel and Spirit: Issues in the New Testament Hermeneutics, Grand Rapids 1991, p. 98.

48 Robert Menzies, Empowered for Witness: The Spirit in Luke-Acts, Sheffield 1994, p. 246.

49 R.Williams, The Pentecostal Reality, p. 23.

50 Roger R. Woodard, Foundation and Principles of New Testament Christianity, Cleveland 1993, p. 159. 
respect and collaboration, a door for listening to the neighbour, and not least a door for ecumenical understanding. Even theological debate has to develop in a spirit of love and acceptance.

Love as a spiritual fruit of the Spirit holds a preeminent position in Christian life. The fruit of the Spirit is not only a spiritual work performed by the Spirit while the Christian individual is in a passive state, but is a cooperation and a process which involves divine sovereignty and human responsibility. ${ }^{51}$

In spite of doctrinal differences concerning pneumatology between Pentecostals and Evangelicals, there is a large gate of mutual acceptance in love between them. This Christian love is not exclusivist and it does not include only Pentecostal or Evangelical families but encompasses also Christians from all denominations such as Eastern-Orthodox, Catholic, Lutheran, and so on. Christian love is not the result of a sustained human effort but is a real result of the presence of the Holy Spirit in the life of Christians. If some Christians claim that the gift of the Spirit ceased with the end of the apostolic age, there is no Christian who affirms that love as the fruit of the Spirit ceased. Moreover, Paul says that „Love never ends! As for prophecies, they will pass away; as for tongues, they will cease; as for knowledge, it will pass away" (I Cor. 13:8). The kingdom of God is the kingdom of love where those who are born from the Spirit of love accept each other. If love is not the pinnacle of Christian life, all the gifts of the Spirit lose their power, meaning and influence.

In the absence of love the Pentecostals cannot speak about the Baptism in the Spirit, nor about spiritual gifts because these spiritual blessings will not operate in a selfish environment. It is right to look back in a historical pilgrimage and to try to imagine the church born birth in the first Century and to realize the blessings of the gifts of the Spirit for the church; but nobody can have a whole picture if they avoid thinking of agape; of that sacrificial love which drove Christians toward personal sacrifice for their fellow human beings. The lesson to be learned here is the lesson of love and acceptance between Pentecostals and Evangelicals where those who were baptized in the Spirit do not despise those who didn't have that experience, but in the same measure those who have different understandings about this baptism do not judge their brothers either. Sharing the love of Christ during this time, by the power of the Spirit, toward every human being throughout the world is not just an option but it is a responsibility of all Christians and is a proof of spiritual empowerment. Rodman Williams noticed the enormous Christian contribution for the contemporary world since we are living in strong globalism as follows: "At the first Pentecost, people were gathered together from

51 John D. Harvey, Anointed with the Spirit and Power, Phillipsburg 2008, p. 182. 
every nation under the heaven in one place, Jerusalem; but now Jerusalem is the world, with Christians in almost every place." ${ }^{2}$ Holy Spirit presence in our world today is crucial because the Spirit has the power to level out the differences between people, to bring comfort in a suffering world in all kinds of crises such as extremism, fundamentalism, and eco-crisis; and so renew it into a better world filled with joy and peace. ${ }^{53}$

52 R.Williams, The Pentecsotal Reality, p. 54.

53 Wilson Varkey, Role of the Holy Spirit in Protestant Systematic Theology, Regensburg 2011, p. 413. 